\title{
Effects of Global Economic Variables to Indonesian Government Securities
}

\author{
Himawan Wiratama ${ }^{1}$, Rifki Ismal ${ }^{2}$ \\ \{himawanwiratama10@gmail.com ${ }^{1}$,rifki_ismal@yahoo.com² \\ University of Indonesia ${ }^{1}$, University of Indonesia ${ }^{2}$
}

\begin{abstract}
This study examines the impact of global economic factors including interest rates, exchange rate, world oil prices, and world gold prices on local currency sovereign conventional bonds and sukuk indices in the Indonesian bond market. The study covers the period August 2009 to December 2018 and uses of the monthly data by applying the dinamic econometric models. The results of this study prove that the movement of the exchange rate, world oil prices, and world gold prices have a significant impact on the movement of the local currency sovereign conventional bonds and sukuk indices in the Indonesian bond market. While global interest rates does not have an effects on the movement of the local currency sovereign conventional bonds and sukuk indices in Indonesian bond market.

Based on this study, bond and sukuk holders need to pay attention to exchange rate, world oil prices, and world gold prices movements. When the bond market conditions are good, gold can be used as an instrument for portfolio diversification, but not vice versa. In maintaining the performance of conventional bonds and sukuk, the Government needs to maintain stability of exchange rate volatility, maintain oil prices to control inflation, and strengthen the domestic investor base. In addition, this study can also enrich the literature in the capital market, especially the Government bond market, both SUN and SBSN.
\end{abstract}

Keywords : Capital Market, Bonds, Sukuk, Interest Rate, Exchange Rate, Oil Price, Gold Price.

\section{Introduction}

Capital market has a function as means to obtain funding for both companies and governments and also as a means to invest both for companies and the community[1]. Capital market is a place for various types of long-term financial instruments that can be traded both in the form of bonds, equity (shares), mutual funds, derivative instruments, and other instruments [2]. To obtain funding through the capital market, the government of Indonesian (GoI) regularly issues bonds/Government Securities (SBN). SBN consisting of Government Bonds (SUN) which are conventional bonds and State Sharia Securities (SBSN)/Sukuk Negara which are bonds based on sharia principles.

The 2019 issuance target is IDR825.69 trillion, consist of SUN issuance at IDR583.69 trillion and SBSN issuance at IDR242.00 trillion [3]. As of February 28, 2019, the outstanding SBN is IDR3,775 trillion, in which the portion of SUN is IDR3,078 trillion $(81.52 \%)$ and SBSN is IDR697 trillion (18.48\%) [4]. As the issuer, GoI have to manage its portfolio by considering its increasing issuance target and its growing outstanding SBN each year, 
especially, in the event of deteriorating economic conditions that lead increase in bond yields in secondary market and lead to increased costs if the Government will issue SBN. So the GoI must close pay attention to economic conditions in considering the timing of SBSN issuance.

Considering the large amount of SBN issuance target and the continued increase in SBN issuance each year, SBN is certainly an investment instrument for idle fund and alternative options for investors in managing their portfolios. The portion of ownership by foreign investors in tradable SBN denominated in Rupiah, data as of February 28, 2019 foreign investors hold SBN instruments of $37.91 \%$ consisting of $44.73 \%$ in SUN instruments and $4.44 \%$ in SBSN instruments [5]. Therefore not only local investors have an interest in looking at both domestic and global factors that can affect the movement of SUN and SBSN prices but also foreign investors. With the deteriorating economic conditions, it could lead to massive sell-offs in the capital market, mainly by foreign investors. This massive selloff will actually worsen the economy by further increasing bond yields on the secondary market. Hence that the global economic conditions affect the flow of foreign funds which have the potential to create a shock to the Indonesian bond market.

Several global factors have proven to affect the performance of the Indonesian capital market. First, the increase in the federal funds rate carried out by the Federal Reserve increases the yield of US Treasury in the United States bond market [6]. This increase draw investors to re-enter the US capital market thus put pressure on emerging country bond yields [7]. Increased US Treasury yields will be responded to by emerging markets such as Indonesia through adjusting bond yields to safeguard investor interest and stabilize economic conditions in Indonesia so that not many foreign investors leave the Indonesian capital market. Second, changes in currency exchange rates also affect the capital market, especially from the point of view of foreign investors holding Rupiah denominated instrument. When the Rupiah to the US Dollar weakens, foreign investors will immediately sell their bonds to minimize the decline in the value of their investment. This sale will reduce prices and increase bond yields. This condition will also increase the Government's emission costs in issuing new bonds.

Third, changes in world oil prices also affect the economic condition of a country, but there are differences in influence between oil-exporting countries and oil-importing countries. The increase in the oil price will provide additional profit for the net exporting countries and more cost for the net-omporting countries. For Indonesian capital market, the increase in world oil prices has an impact on the increase in bond yields expected by investors due to fears of an increase in inflation caused by rising oil prices [8], [9]. This shows that oil prices can affect the economy of a country so that oil prices are an indicator of changes in economic conditions and changes in capital markets. Fourth, gold is a commodity that can be used as a means of investing, thus is a substitute for capital market instruments. Any changes in gold prices will affect investors interest in deciding to buy or sell their investments in the capital market which will cause the price movements of the bonds themselves.

Considering all of those factors and the limited research on these factors towards the Indonesian government bond market instruments, it is very important to assess the impact of global economic, especially the US benchmark interest rate, the exchange rate of US Dollar to Rupiah, world oil prices, and world gold prices on SUN and SBSN. The rest of the study is organized as follows: in section 2 explores literature review related to this study, the methodology is presented in section 3, result and analysis is studied in section 4, and section 5 discusses conclusion and recommendation the study. 


\section{Literature Review}

Reference [10] and [11] are comprehensive research to find out the determinants of bond spreads. Based on this research, global economic variables can be reflected in external shocks, namely world oil prices and US benchmark interest rates and macroeconomic fundamental variables that are influenced by global conditions, namely exchange rates. Besides that, this study also use the world gold price variable based on previous research that analyzes the effect of gold prices on equities, bonds, and domestic credit, the results show that gold prices significantly affect the bond market and equity [12].

\subsection{Relationship between Interest Rates and Capital Market Performance}

One of the risks faced by bondholders is market risk such as interest rate risk, arising from price movements in financial markets [13]. Interest rate risk is the possibility of changes in interest rates that cause the actual rate of return received from bonds different from the expected return [14]. Practically, the increase in the US benchmark interest rate (the Federal Funds Rate) will have an impact on the increase in US Treasury yields and this will make investors more interested to US capital market instruments (bonds) because returns increase. The increase will cause capital inflows and decreases will cause capital outflows to get an attractive return. The flow of foreign funds into the SUN market has resulted in a decrease in the average interest rates of government bonds [15]. This is in line with the results of research that long-term increases in world interest rates make foreign investors reluctant to buy Spanish bonds [16]. The performance of the Indonesian domestic bond market tended to be negative in 2018 due to expectations of a more aggressive increase in the Fed Funds Rate [17].

The impact of changes in interest rates on returns and volatility of both conventional and Islamic stocks and bonds have a significant impact, but the direction and magnitude of the impacts significantly vary in different countries [18]. However, other findings prove that the impact of worsening global risk sentiment on the yield of government bonds in local currencies in developing countries causes bond yields to fall rather than increase as historical experience [19]. In addition, different findings proved that external shocks measured using real oil prices and international interest rates did not significant for determining bond spreads [10].

From several previous studies, it can be concluded that interest rates can significantly affect the bond market, but with the different direction and magnitude of the impact in each country. But it can also not significantly affect the bond market.

\subsection{Relationship between Exchange Rates and Capital Market Performance}

In addition to interest rate, the risks faced by bondholders arise because price movements in financial markets are exchange rate risk [13]. Since August 1997, the exchange rate has been determined by supply and demand strength for foreign exchange in the market and Bank of Indonesia can only be interventions to stabilize and avoid volatility [20]. Uncertainty in exchange rates will trigger home bias which purpose is to maximize returns in their own country and minimize uncertainty by reducing their investment activities in other countries [21], [22]. The decline in the value Euro to US Dollar which is expected to cause investors to reduce the amount of investment in Spain and increase the yield of Spanish government bonds [16]. 
Greater foreign inflows tend to significantly reduce long-term government bond yields [23]-[25] and provides additional financing and reduces yield rates [26]. In the European Union, 10 percent increase in the portion of bond ownership held by non-residents causes a decrease in yield of 32-43 basis points, and up to 66 basis points [27]. While developing countries that are able to attract more foreign ownership in their local currency government bonds enjoy lower yields [28]. Therefore, mainly foreign investors, if there is a change in exchange rates, they are faced with the existence of gains or losses from their investment in bonds in the denomination of the local currency.

Bond yields in local currencies in developing countries (EME) are influenced by exchange rate risk from expected volatility and exchange rate depreciation [29]. The real exchange rate is also found to have a significant influence in determining bond spreads [10]. Lower nominal effective exchange rates expected have caused Spanish government bond yields to rise or reduce bond prices and vice versa [16], [19], [30], [31]. Otherwise, when the exchange rate is stable or volatility is lower which reduces the uncertainty systematically proven to reduce bond yields in the local currency [29]. The same results also found that high returns on local currency bonds of EME countries were offset by high volatility of the EME exchange rate [19].

From some of the previous studies, there are similarities in the results that the exchange rate has a significant effect on the performance of bonds. The weakening of the local currency exchange rate will cause a yield increase or a decrease in bond prices. This is due to a reduction in the amount of investor funds invested in the country due to a decrease in returns obtained and a higher potential return in the country of origin.

\subsection{Relationship between Oil Prices and Capital Market Performance}

The increase in world oil prices has an impact on the capital market, namely the increase in bond yields expected by investors due to concerns about inflation caused by rising oil prices. Because the increase in energy prices is driving up production costs, so to maintain profits need to make price adjustments [9]. This shows that oil prices can affect the economic conditions of a country so that oil prices are an indicator that determine changes in economic conditions and changes in capital markets. The results of research in the US bond market show that there is a statistically significant relationship between the oil and bond markets where it is also shown that the degree of spillover between the oil and bond markets is very high during 2008-2011 [32]. While research in Nigeria shows that there is a significant symbiotic relationship with the transmission of strong two-way cross-market volatility between oil and the Nigerian government bond market [33].

Different results were found about the direction of the impact caused by certain conditions. In the Middle East, financial uncertainty, economic policy, and world oil have a negative impact and causal effects on Gulf Cooperation Council (GCC) sukuk returns on lower quantiles or bearish markets [34]. In the United States was found that falling oil prices increased uncertainty and hurt risk assets (US stocks and high-yield corporate bonds) and raised safe assets (bonds long-term level of investment and Treasury bonds in the US) [35]. Impact of oil price shocks on the bond in the high oil prices period was statistically significant but in low oil prices it was not statistically significant [36]. The correlation between oil prices and bonds during the spring of 2016 showed a negative and weak correlation, but positive and strong correlation from March to June 2017 [37]. But the different results found that oil price volatility did not show a significant effect on the Russian bond return [38]. 
From a number of previous studies it was found that there was a significant relationship between oil and bond prices, but the direction of the relationship showed different results and between certain time frames showed different directions between studies.

\subsection{Relationship between Gold Prices and Capital Market Performance}

In practice some analysts use gold as a predictor of changes in economic variables [39]. Gold prices are significantly affect the bond market and equity [12]. Positive (negative) shocks to gold prices produce a slow decline (increase) in bond prices [40]. US government bond yields show an inverse correlation with changes in gold prices and this shows a pattern that changes in direction of gold prices are followed by significant movements in bond prices [39].

Different result were found that the Gulf Cooperation Council (GCC) sukuk return was not affected by the uncertainty of conventional bond and gold markets [34]. Gold has low and slightly negative correlation with stocks and bonds remains a positive influence from the perspective of portfolio construction [41]. In South Africa that gold did act as a safe haven when the bond market fell within a certain range but gold can significantly function as a hedge for bond markets [42]. But the role of gold in portfolio diversification in the French capital market shows that gold is good for diversifying stock portfolios but not for bond portfolios [43]. Gold is a safe place for stocks, but gold is generally not a safe place for bonds [44]. Gold cannot functioned as a safe haven for the Indonesian capital market but can act as a strong safe haven for the Malaysian capital market and gold cannot be hedged for the Indonesian stock market but gold can function as diversification both in the Indonesian and Malaysian capital markets [45].

In this regard, this study test four prominent hypotheses: the first hypothesis is that global interest rate negatively related and significant with SUN and SBSN indices. The second is that exchange rate negatively related and significant with SUN and SBSN indices. The third is that world oil price negatively related and significant with SUN and SBSN indices. And the fourth is that world gold price negatively related and significant with SUN and SBSN indices.

\section{Methodology}

Based on its objectives, this study belongs to empirical research and uses quantitative methods. This method is expected to be able to test hypotheses, by examining the relationship between global economic variables on SUN and SBSN and looking for differences in the effect produced by the dependent variable on the two independent variables studied. This study uses a dinamic econometric models known as autoregressive-distributed lag (ARDL).

\subsection{Data and variables}

The variables that will be processed using data as summarized in the Table 1 below:

Table 1. Description Variables

\begin{tabular}{ll}
\hline \multicolumn{1}{c}{ Variables } & \multicolumn{1}{c}{ Description } \\
SUN (SUN) & $\begin{array}{l}\text { The SUN total return index provided by IBPA is the return from } \\
\text { tradable SUN series in Rupiah }\end{array}$ \\
SBSN (SBSN) & $\begin{array}{l}\text { The SBSN total return index provided by IBPA is a return from } \\
\text { tradable SBSN series in Rupiah }\end{array}$ \\
\hline
\end{tabular}




\begin{tabular}{ll}
\hline $\begin{array}{l}\text { Global Reference Rate } \\
\text { (FFR) }\end{array}$ & $\begin{array}{l}\text { The Fed Funds Rate provided by the Federal Reserve which is the } \\
\text { United States of America central bank (percentage) }\end{array}$ \\
$\begin{array}{l}\text { Exchange Rate US Dollar to } \\
\text { Rupiah (KURS) }\end{array}$ & $\begin{array}{l}\text { Exchange Rate US Dollar to Rupiah provided by Bank Indonesia } \\
\text { (IDR/USD) }\end{array}$ \\
World Oil Prices (OIL) & $\begin{array}{l}\text { West Texas Intermediate/WTI world oil prices provided by NYMEX } \\
\text { (USD/barrel) }\end{array}$ \\
World Gold Prices (GOLD) & World gold prices provided by COMEX (USD/troy ounce) \\
\hline
\end{tabular}

The SUN total return index (INDOBeX government total returns) and the SBSN total return index (Indonesian government sukuk index / IGSIX total returns) provided by the Indonesia Bond Pricing Agency (IBPA). This index describes the movement of the rate of return of the entire bond where the calculation is based on the increase or decrease in bond prices, accumulated coupons, and return of annual coupons that are reinvested so that the index is more accurate in describing the performance of bonds [17].

To explain the interest rate, this study uses the Federal Funds Rate (FFR) issued by the Federal Reserve which is the central bank of the United States of America. The Fed Funds Rate is the base interest rate for commercial bank activities and FFR is the interest rate charged by banks to other banks for overnight loans with nominal $\$ 1$ million or more [46]. The Fed Funds Rate is the most important interest rate in the world because of the dominance of the US Dollar in the world trade and payment system. For exchange rates US Dollar to Rupiah, we use data provided daily by the Indonesian Central Bank.

For world oil price, this study uses price of West Texas Intermediate (WTI) oil, which is high-quality oil with low sulfur content, making it suitable for fuel. This oil price data is provided by the New York Mercantile Exchange, Inc. (NYMEX) which is the largest commodity futures exchange in the world located in the city of New York, United States. While for the world gold price, we use world gold prices provided by the New York Commodities Exchange (COMEX) division.

\subsection{Correlation Test}

Correlation analysis aims to measure the degree of relationship/strength of linear associations between 2 (two) variables [47]. The correlation is described by the degree index of the relationship called the correlation coefficient [48]. The correlation coefficient shows two things, namely the magnitude of the relationship and the direction of the relationship. Correlation coefficients are classified into 5 (five) parts are $0,800-1,000$ very strong relationship, 0,600 - 0,799 strong relationship, 0,400 - 0,599 moderate relationship, 0,2000,399 weak relationship, and 0,000 - 0,199 very weak relationship [49].

\subsection{Causality Test}

Regression models show a unidirectional causality relationship where the independent variable is the cause and the dependent variable as a result. Not only is there a causal relationship that must be proven, but the direction of cause and effect must also be known [47]. But these two variables can also have two-way relationships that influence and are influenced or commonly referred to as simultaneous relations. To identify the existence of this relationship, a granger causality test can be used. This granger causality test is used to indicate whether a variable has a two-way relationship, or only one direction or it does not find a relationship between the two. 


\subsection{Stationarity Test}

Data sets are declared stationary if the average/mean and variants values of the time series data do not change systematically over time or some experts state the average/mean and the variants are constant [50]. Data is stationary if the mean and autocovariance of the data series do not depend on time [51]. Not stationary data can have an impact on the poor model estimated as well as due to autocorrelation and heteroscedasticity which have the same properties as the data that is not stationary. To ensure this stationarity, the unit root test can be used.

\subsection{Dinamic Econometric Models}

The analytical model used in this study is a dynamic econometric model. This is a further model of the multivariate regression model with the ordinary least square (OLS) equation. In a dynamic econometric model using time series data, the variables used in the regression model also include the lag values of both the dependent variable and the independent variable [52]. If the regression model includes the lag value of the independent variable then it is called the distributed-lag model and if the regression model includes the past value of the independent variable then it is called the autoregressive model [52]. According to reference [52] also that OLS method can also be applied using lag based on the approach taken by reference [53] \& [54]. Dinamic econometric model used to express the relationship between the dependent variable and the independent variable in this study was formulated with a model, namely:

$$
\begin{aligned}
& \operatorname{SUN}_{\mathrm{t}}=\alpha+\gamma \mathrm{SUN}_{\mathrm{t}-\mathrm{k}}+\beta_{1} \mathrm{FFR}_{\mathrm{t}}+\beta_{\mathrm{k}} \mathrm{FFR}_{\mathrm{t}-\mathrm{k}}+\beta_{2} \mathrm{KURS}_{\mathrm{t}}+\beta_{\mathrm{k}} \mathrm{KURS}_{\mathrm{t}-\mathrm{k}}+\beta_{3} \mathrm{OIL}_{\mathrm{t}}+ \\
& \beta_{\mathrm{k}} \mathrm{OIL}_{\mathrm{t}-\mathrm{k}} \beta_{4} \mathrm{GOLD}_{\mathrm{t}}+\beta_{\mathrm{k}} \mathrm{GOLD}_{\mathrm{t}-\mathrm{k}}+\varepsilon_{i} \\
& \mathrm{SBSN}_{\mathrm{t}}=\alpha+\gamma \mathrm{SBSN}_{\mathrm{t}-\mathrm{k}}+\beta_{1} \mathrm{FFR}_{\mathrm{t}}+\beta_{\mathrm{k}} \mathrm{FFR}_{\mathrm{t}-\mathrm{k}}+\beta_{2} \mathrm{KURS}_{\mathrm{t}}+\beta_{\mathrm{k}} \mathrm{KURS}_{\mathrm{t}-\mathrm{k}}+\beta_{3} \mathrm{OIL}_{\mathrm{t}}+ \\
& \beta_{4} \mathrm{GOLD}_{\mathrm{t}}+\beta_{\mathrm{k}} \mathrm{GOLD}_{\mathrm{t}-\mathrm{k}}+\varepsilon_{i}
\end{aligned}
$$

Where:

$$
\begin{aligned}
& \text { SBSN }_{t}=\text { IBPA SBSN total return index } \quad \text { KURS }_{t-k}=\text { Previous period Exchange Rate } \\
& \mathrm{SBSN}_{\mathrm{t}-\mathrm{k}}=\text { Previous period IBPA SBSN total United States Dollar to Rupiah } \\
& \text { return index } \quad \mathrm{OIL}_{\mathrm{t}} \quad=\text { World Crude Oil Price (WTI) } \\
& \mathrm{SUN}_{\mathrm{t}}=\text { IBPA SUN total return index } \quad \mathrm{OIL}_{\mathrm{t}-\mathrm{k}} \quad=\text { Previous period World Crude Oil } \\
& \mathrm{SUN}_{\mathrm{t}-\mathrm{k}}=\text { Previous period IBPA SUN total Price (WTI) } \\
& \text { return index } \quad \text { GOLD }_{\mathrm{t}}=\text { World Gold Price (COMEX) } \\
& \mathrm{FFR}_{\mathrm{t}}=\text { US Reference Rate, which is the } \mathrm{GOLD}_{\mathrm{t}-\mathrm{k}}=\text { Previous period World Gold Price } \\
& \text { Fed Funds Rate (COMEX) } \\
& \mathrm{FFR}_{\mathrm{t}-\mathrm{k}}=\text { Previous period US Reference } \quad \alpha \quad=\text { Constant (intercept) } \\
& \text { Rate, which is the Fed Funds Rate } \beta_{\mathrm{i}}=\text { Regression coefficient of the } \\
& \mathrm{KURS}_{\mathrm{t}}=\text { Exchange Rate United States independent variable (slope) } \\
& \text { Dollar to Rupiah } \quad \varepsilon_{\mathrm{i}} \quad=\text { Residual (standard error) }
\end{aligned}
$$

\section{Result \& Analysis}

Table 2 presents the descriptive statistics of the time series data set. The time period of the data is August 2009 to December 2018. 
Table 2. Descriptive Statistics of the Variables

\begin{tabular}{lcccccc}
\hline & SBSN & SUN & FFR & KURS & OIL & GOLD \\
Mean & 160.5319 & 174.2928 & 0.555310 & 11488.57 & 74.46823 & 1328.357 \\
Median & 155.5000 & 170.2793 & 0.250000 & 11717.00 & 77.00000 & 1281.300 \\
Maximum & 220.2952 & 242.9325 & 2.500000 & 15227.00 & 113.9300 & 1829.300 \\
Minimum & 100.2326 & 100.6995 & 0.250000 & 8508.000 & 33.62000 & 952.2000 \\
Std. Dev. & 33.98904 & 38.62219 & 0.569632 & 2077.856 & 21.90915 & 193.3878 \\
Skewness & 0.214318 & 0.074451 & 1.881586 & -0.027512 & -0.126894 & 0.829131 \\
Kurtosis & 2.101966 & 2.153131 & 5.372712 & 1.405847 & 1.653132 & 2.872894 \\
Observations & 113 & 113 & 113 & 113 & 113 & 113 \\
\hline
\end{tabular}

SUN total return index rose higher compared to SBSN total return index because before this index was formed, outstanding SUN had reached 46 series with a total of IDR377 trillion while SBSN had only 3 series with IDR10 trillion where the coupons were quite high with a range of $9 \%-15.575 \%$ [4]. Some of the SUN series are also currently being traded on the secondary market, so they still give high coupons to investors, while the SBSN series are all mature.

\subsection{Correlation Test}

Table 3. Correlation Test Result

\begin{tabular}{ccccc}
\hline & FFR & KURS & OIL & GOLD \\
SBSN & 0.791982 & 0.847860 & -0.584009 & -0.125655 \\
SUN & 0.762866 & 0.818619 & -0.563199 & -0.067538 \\
\hline
\end{tabular}

From Table 3 above, it can be seen that the Fed Funds Rate have a strong positive correlation with SUN and SBSN. Exchange rates have a very strong positive correlation with SUN and SBSN. World oil prices have a moderate negative correlation with SUN and SBSN. Different from the previous 3 variables, world gold prices have a very weak negative correlation with SUN and SBSN. Because gold investment can be a safe place when the bond market falls and gold is significantly a hedge for bonds [42]. So that the low and negative correlations of gold with these bonds remain a positive influence from the perspective of portfolio construction [41]. It can also be seen from Table 3 that the SBSN correlation value is higher than the SUN in all of these variables.

\subsection{Causality Test Result}

Table 4. Granger Causality Test Result

\begin{tabular}{cccccc}
\hline \multicolumn{1}{c}{ Variables } & \multicolumn{2}{c}{ SBSN } & \multicolumn{2}{c}{ SUN } \\
& P-Value & Result & P-Value & Result \\
FFR does not Granger Cause SBSN/SUN & 0.8722 & Do not reject $\mathrm{H}_{0}$ & 0.7737 & Do not reject $\mathrm{H}_{0}$ \\
SBSN/SUN does not Granger Cause FFR & 0.2360 & Do not reject $\mathrm{H}_{0}$ & 0.3405 & Do not reject $\mathrm{H}_{0}$ \\
KURS does not Granger Cause SBSN/SUN & 0.0602 & Do not reject $\mathrm{H}_{0}$ & 0.1323 & Do not reject $\mathrm{H}_{0}$ \\
SBSN/SUN does not Granger Cause KURS & 0.1193 & Do not reject $\mathrm{H}_{0}$ & 0.1083 & Do not reject $\mathrm{H}_{0}$ \\
OIL does not Granger Cause SBSN/SUN & 0.1105 & Do not reject $\mathrm{H}_{0}$ & 0.0515 & Do not reject $\mathrm{H}_{0}$ \\
SBSN/SUN does not Granger Cause OIL & 0.2576 & Do not reject $\mathrm{H}_{0}$ & 0.2389 & Do not reject $\mathrm{H}_{0}$ \\
DGOLD does not Granger Cause DSBSN/DSUN & 0.0044 & Reject $\mathrm{H}_{0}$ & 0.0170 & Reject $\mathrm{H}_{0}$ \\
DSBSN/DSUN does not Granger Cause DGOLD & 0.4966 & Do not reject $\mathrm{H}_{0}$ & 0.3906 & Do not reject $\mathrm{H}_{0}$ \\
\hline
\end{tabular}


The world gold price variable affects the dependent variable, namely the SBSN and SUN index. While other dependent variables individually did not affect the SBSN and SUN index and the dependent variable did not affect the four independent variables. But this only shows the relationship between variables individually. Later in the regression model created, determine the relationship of the overall independent variables together on the dependent variable.

\subsection{Stationarity Test Result}

The test that can be used to find out stationary data is the unit root test. We use two types unit root test, namely Augmented Dickey Fuller (ADF) and Phillips-Perron. Each type of unit root test can be done at the level and $1^{\text {st }}$ differential. The ADF and Phillips-Peron test results are as the table 5 below:

Table 5. Augmented Dickey Fuller and Phillips-Peron Test Result

\begin{tabular}{lcccccccc}
\hline \multirow{2}{*}{ Variable } & \multicolumn{4}{c}{ Augmented Dickey Fuller } & \multicolumn{4}{c}{ Phillips-Peron } \\
& Level & Result & $1^{\text {st }}$ Diff & Result & Level & Result & $1^{\text {st }}$ Diff & Result \\
SBSN & $0.8796 *$ & Non-Stationary & 0.00 & Stationary & $0.8747 *$ Non-Stationary & 0.00 & Stationary \\
SUN & $0.7382 *$ & Non-Stationary & 0.00 & Stationary & $0.7382 *$ Non-Stationary & 0.00 & Stationary \\
FFR & $0.9980 *$ & Non-Stationary & $0.9913 *$ & Non-Stationary & $1.0000 *$ Non-Stationary & 0.00 & Stationary \\
KURS & $0.9481 *$ & Non-Stationary & 0.00 & Stationary & $0.9483 *$ Non-Stationary & 0.00 & Stationary \\
OIL & $0.7059 *$ & Non-Stationary & 0.00 & Stationary & $0.6259 *$ Non-Stationary & 0.00 & Stationary \\
GOLD & $0.1482 *$ & Non-Stationary & 0.00 & Stationary & $0.1802 *$ Non-Stationary & 0.00 & Stationary \\
\hline
\end{tabular}

Note: * indicates NOT significant at $1 \%, 5 \%$ or $10 \%$ level

From the results at 1 st different Phillips-Peron test, it is known that all have been stationary so that data processing can be carried out at a later stage.

\subsection{Dinamic Econometric Models}

The results of the SBSN regression are as follows:

Table 6. Dinamic Econometric Models Estimations for SBSN

\begin{tabular}{lrrlr}
\hline \multicolumn{1}{c}{ Variable } & Coefficient & \multicolumn{1}{c}{ Prob. } & & Value \\
C & 1.226533 & 0.0000 & Prob(F-statistic) & 0.000000 \\
DKURS & -0.005307 & 0.0000 & R-squared & 0.510102 \\
DOIL & -0.064560 & 0.0379 & Durbin-Watson stat & 1.905255 \\
DGOLD & 0.008576 & 0.0027 & & \\
DGOLD(-1) & 0.008618 & 0.0019 & & \\
DGOLD(-2) & 0.007428 & 0.0070 & & \\
\hline
\end{tabular}

From the results of the dinamic econometric model, it was found that the SBSN index (SBSN) was influenced by the exchange rate of US Dollar to Rupiah (KURS), world oil prices (OIL), world gold prices (GOLD), world gold prices 1 month earlier (GOLD(-1)), and world gold prices 2 month earlier $(\operatorname{GOLD}(-2))$. The coefficients for all the variables above are with proper sign and statistically significant at the 5 percent level. The coefficients of the variables exchange rate of US Dollar to Rupiah (KURS), world oil prices (OIL) are found to be negative but significant and the coefficients of the variables world gold prices (GOLD), world gold prices 1 month earlier $(\operatorname{GOLD}(-1))$, and world gold prices 2 month earlier $(\operatorname{GOLD}(-2))$ are

$$
\begin{aligned}
\Delta \mathrm{SBSN}_{\mathrm{t}}= & 1,226533-0,005307 \Delta(\mathrm{KURS})_{\mathrm{t}}-0,064560 \Delta(\mathrm{OIL})_{\mathrm{t}}+0,008576 \Delta(\mathrm{GOLD})_{\mathrm{t}} \\
& +0,008618 \Delta(\mathrm{GOLD})_{\mathrm{t}-1}+0,007428 \Delta(\mathrm{GOLD})_{\mathrm{t}-2}+\varepsilon_{i}
\end{aligned}
$$


found to be positive and significant. However, the Fed Funds Rate variable has no eff, changes in the SBSN index. So that the model formed is as follows:

The model of the equation above shows that an increase in the exchange rate of 1 Rupiah per US Dollar will reduce the SBSN index by 0.005307 . The increase in world oil prices by 1 US Dollar per barrel will reduce the SBSN index by 0.064560 . The gold price increase of US $\$ 1$ per troy ounce will increase the SBSN index by 0,008576 . The increase in the gold price 1 month earlier of 1 US Dollar per troy ounce will increase the SBSN index by 0.008618 . And the increase in the gold price 2 month earlier of 1 US Dollar per troy ounce will increase the SBSN index by 0.007428 .

The resulting model is quite reliable, as evidenced from the results of the classic assumption test as follows:

Table 7. Classical Assumptions Test Result for SBSN

\begin{tabular}{lrc}
\hline Autocorrelation Test & \multicolumn{1}{c}{ Value } & Result \\
$\quad$ Prob. Chi-Square(2) & & \\
Multicollinearity Test & & Do not reject $\mathrm{H}_{0}$ \\
DKURS & 1.104066 & \\
DOIL & 1.066343 & There is no \\
DGOLD & 1.150429 & Multicolinearity \\
DGOLD(-1) & 1.075627 & \\
DGOLD(-2) & 1.076306 & \\
Heteroskedasticity Test & & \\
$\quad$ Prob. Chi-Square(5) & 0.2167 & Do not reject $\mathrm{H}_{0}$ \\
Normality Test & & \\
$\quad$ Skewness & -0.162354 & \\
$\quad$ Kurtosis & 3.032821 & Do not reject $\mathrm{H}_{0}$ \\
$\quad$ Prob Jarque Bera & 0.488184 & \\
\hline
\end{tabular}

From the results of the classical assumptions test, it was proven that the data did not contain autocorrelation, had been homoscedastic, did not contain multicollinearity, and had been normally distributed.

The results of the SUN regression are as follows:

Table 8. Dinamic Econometric Models Estimations for SUN

\begin{tabular}{lrr|lr}
\hline \multicolumn{1}{c}{ Variable } & Coefficient & Prob. & & Value \\
C & 1.502093 & 0.0000 & Prob(F-statistic) & 0.000000 \\
DKURS & -0.009110 & 0.0000 & R-squared & 0.502345 \\
DOIL & -0.101200 & 0.0494 & Durbin-Watson stat & 2.035423 \\
DGOLD & 0.013737 & 0.0037 & & \\
DGOLD(-1) & 0.011421 & 0.0124 & & \\
DGOLD(-2) & 0.009458 & 0.0369 & & \\
\hline
\end{tabular}

From the results of the dinamic econometric model, it was found that the SUN Index (SUN) was influenced by the exchange rate of US Dollar to Rupiah (KURS), world oil prices (OIL), world gold prices (GOLD), world gold prices 1 month earlier (GOLD(-1)), and world gold prices 2 month earlier $(\operatorname{GOLD}(-2))$. It is found that the coefficients for all the variables above are with proper sign and statistically significant at the 5 percent level. The coefficients of the variables exchange rate of US Dollar to Rupiah (KURS), world oil prices (OIL) are

$$
\begin{aligned}
\Delta \mathrm{SUN}_{\mathrm{t}}= & 1,502093-0,009110 \Delta(\mathrm{KURS})_{\mathrm{t}}-0,101200 \Delta(\mathrm{OIL})_{\mathrm{t}}+0,013737 \Delta(\mathrm{GOLD})_{\mathrm{t}} \\
& +0,011421 \Delta(\mathrm{GOLD})_{\mathrm{t}-1}+0,009458 \Delta(\mathrm{GOLD})_{\mathrm{t}-2}+\varepsilon_{i}
\end{aligned}
$$


found to be negative but significant and the coefficients of the variables world gold prices (GOLD), world gold prices 1 month earlier (GOLD(-1)), and world gold prices 2 month earlier (GOLD(-2)) are found to be positive and significant. However, the Fed Funds Rate variable has no effect on changes in the SUN index. So that the model formed is as follows:

The model of the equation above shows that an increase in the exchange rate of 1 Rupiah per US Dollar will reduce the SUN index by 0.009110 . The increase in world oil prices by 1 US Dollar per barrel will reduce the SUN index by 0.101200 . The gold price increase of US \$ 1 per troy ounce will increase the SUN index by 0,013737 . The increase in the gold price 1 month earlier of 1 US Dollar per troy ounce will increase the SUN index by 0.011421 . And the increase in the gold price 2 month earlier of 1 US Dollar per troy ounce will increase the SUN index by 0.009458 .

The resulting model is quite reliable, as evidenced from the results of the classic assumption test as follows:

Table 9. Classical Assumptions Test Result for SUN

\begin{tabular}{lrc}
\hline Autocorrelation Test & Value & Result \\
$\quad$ Prob. Chi-Square(2) & & \\
Multicollinearity Test & 0.9552 & Do not reject $\mathrm{H}_{0}$ \\
DKURS & 1.104066 & \\
DOIL & 1.066343 & There is no \\
DGOLD & 1.150429 & Multicolinearity \\
DGOLD(-1) & 1.075627 & \\
DGOLD(-2) & 1.076306 & \\
Heteroskedasticity Test & & \\
$\quad$ Prob. Chi-Square(3) & 0.8985 & Do not reject $\mathrm{H}_{0}$ \\
Normality Test & & \\
$\quad$ Skewness & 0.194206 & \\
$\quad$ Kurtosis & 2.978014 & Do not reject $\mathrm{H}_{0}$ \\
$\quad$ Prob Jarque Bera & 0.710891 & \\
\hline
\end{tabular}

From the results of the classical assumptions test, it was proven that the data did not contain autocorrelation, had been homoscedastic, did not contain multicollinearity, and had been normally distributed.

We find that the exchange rate to both the SUN and SBSN markets is in line with the literature, the expected decline in value from the Euro versus US Dollar leads to an increase in Spanish government bond yields [16] and in developing countries (EME) [30] [19]. It is shown that the exchange rate weakened drastically in the period 2013 and 2018 (the exchange rate crisis) caused a decrease in the total return index of SUN and SBSN. The weakening of the exchange rate also made the percentage of foreign ownership of SBN decline compared to the previous year because foreign investors left the Indonesian bond market and refrained from entering Indonesian market bonds. This is in line with previous research where the weakening of the exchange rate caused a decline in foreign ownership [16], [21], [22].

The exchange rate crisis was caused by the trade balance deficit in the period 2012-2014, and 2018 amounted to USD1.7 billion, USD4.1 billion, USD2.2 billion, and USD8.6 billion 
[55][56]. The Indonesian Government's strategy is to prioritize debt in Rupiah so that it remains resilient to exchange rate fluctuations and broadens the domestic investor base to deepen the market while controlling the portion of foreign ownership [15].

World oil prices have a negative correlation on the index of SUN and SBSN. This shows that Indonesia's bond market position is less favorable to changes in oil prices. This is because Indonesia's crude oil exports are lower than imports since 2013, which puts Indonesia as a net importer. The coefficient of oil prices will depend on the nature of the country, if the country is the oil consuming country, the aggregate impact is found to be negative, but conversely, if it is an oil exporting country, it will be positive [8].

World gold prices have a positive correlation on the index of SUN and SBSN indicating that gold has the similar properties as bonds. So that gold does not act as a safe haven for the SBSN and SUN markets. Indonesian people are still very limited who understand about the bond market while gold is an instrument that has always been an investment vehicle for the Indonesian people. So the bond market has a separate market where between the two instruments are not complementary but replace each other. These results support the findings that gold is not a good instrument for portfolio diversification for the capital market [43], [44] and $[45]$.

\section{Conclusion \& Recommendation}

This study examines the impact of global economic factors including interest rates, exchange rates, world oil prices, and world gold prices on local currency sovereign conventional bonds and sukuk indices in the Indonesian capital market. The study covers the period of August 2009 to December 2018 and uses the monthly data by applying the dinamic econometric models. The result indicates that exchange rates, world oil prices, and world gold prices have significant impact on the movement of the local currency sovereign conventional bonds and sukuk indices in Indonesia capital market. While global interest rates does not have effects on the movement of the local currency sovereign conventional bonds and sukuk indices in Indonesian capital market. Thus for investors who want to invest in SUN and SBSN to pay attention to the exchange rate US Dollar to Rupiah, world oil prices, and world gold prices movements.

Exchange rates as macroeconomic variables whose movements can still be intervened, Bank Indonesia needs to ensure that volatility is maintained. In order to safeguard foreign funds invested in the Indonesian bond market, it did not come out massively when domestic economic conditions deteriorated. The government also needs to make policies by establishing a safe portion for foreign ownership on SBN. The government can also issue instruments that can only be held by domestic investors especially needs to maximize the potential of the millennial generation to invest in SBN instruments. The government needs to be careful in determining fuel pricing policies because rising prices can have the effect of inflation, which will increase the expected yield of bonds. But the Government also needs to consider the allocation of fuel subsidies in the government budget to remain within safe limits.

Investors can use gold as a portfolio diversification instrument when the bond market conditions are good. But in the event that the bond market conditions are bad, investors need to consider alternative investment instruments other than gold as a safe haven instrument. To anticipate uncertainties in global economic conditions that affect the market performance of 
SBSN and SUN, the Government still needs to consider the flexibility of the calendar of issuance. The government also needs to carry out a front loading strategy to avoid cornering at the end of the year in the event that the SBN issuance target is still quite large. This policy is to maintain the achievement of SBN issuance targets and keep SBN issuance costs efficient.

\section{References}

[1] "Pasar Modal," Financial Services Authority, 2019. [Online]. Available: https://www.ojk.go.id/sustainable-finance/id/tentang/Pages/PasarModal.aspx.

[2] Indonesia Stock Exchange, "Pengantar pasar modal," 2019. .

[3] Ministry of Finance of Republic of Indonesia, "Materi presentasi SBR006," 2019. .

[4] Ministry of Finance of Republic of Indonesia, "Posisi surat berharga negara," 2019. .

[5] Ministry of Finance of Republic of Indonesia, "Kepemilikan SBN domestik yang dapat diperdagangkan,” 2019. .

[6] Federal Reserve, "Function Conducting Monetary Policy," 2019. .

[7] IBPA, "Review Ekonomi dan pasar obligasi tahun 2018," 2019. .

[8] S. H. Naidu A, P. Goyari, and B. Kamaiah, "Determinants of sovereign bond yields in emerging economies: Some panel inferences," Theor. Appl. Econ., vol. XXIII, no. 3(608), pp. 101-118, 2016.

[9] P. Yusgiantoro and L. Yusgiantoro, Ekonomi dan energi: Teori dan aplikasi. Jakarta: Yayasan Purnomo Yusgiantoro, 2018.

[10] H. G. Min, "Determinants of emerging do economic fundamentals matter?," World Bank, Policy Res. Work. Pap., no. March 1998, 1998.

[11] H. Min, D. Lee, C. Nam, M. Park, and S. Nam, "Determinants of emerging-market bond spreads : cross-country evidence," Glob. Financ. $J$. , vol. 14, pp. 271-286, 2003, doi: 10.1016/j.gfj.2003.10.001.

[12] S. M. Ziaei, "Effects of gold price on equity, bond and domestic credit: evidence from ASEAN +3," Procedia - Soc. Behav. Sci., vol. 40, pp. 341-346, 2012, doi: 10.1016/j.sbspro.2012.03.197.

[13] M. Choudhry, An introduction to bond markets, Fourth Ed. Chichester: John Wiley \& Sons, 2010. 
[14] R. S. Johnson, Debt Markets and Analysis. New Jersey: John Wiley \& Sons, 2013.

[15] Fiscal Policy Agency, Tinjauan ekonomi, keuangan, \& fiskal: Fiskal yang solid di tengah volatilitas perekonomian triwulan III 2018. Jakarta: Fiscal Policy Agency, 2018.

[16] Y. Hsing, "Determinants of the government bond yield in Spain: A loanable funds model," Int. J. Financ. Stud., vol. 3, no. 3, pp. 342-350, 2015, doi: 10.3390/ijfs3030342.

[17] Indonesia Stock Exchange and Indonesia Bond Pricing Agency, Indonesia Bond Market Directory 2018-2019. Jakarta: PT Bursa Efek Indonesia, 2018.

[18] S. Akhtar, F. Akhtar, M. Jahromi, and K. John, "Impact of interest rate surprises on islamic and conventional stocks and bonds," J. Int. Money Financ., vol. 79, no. 2017, pp. 218-231, 2017, doi: 10.1016/j.jimonfin.2017.09.003.

[19] K. Miyajima, M. S. Mohanty, and T. Chan, "Emerging market local currency bonds: Diversification and stability," Emerg. Mark. Rev., vol. 22, pp. 126-139, 2015, doi: 10.1016/j.ememar.2014.09.006.

[20] I. Simorangkir, Pengantar kebanksentralan: Teori dan praktik di Indonesia. Jakarta: Raja Grafindo Persada, 2014.

[21] G. M. Caporale, F. Menla Ali, and N. Spagnolo, "Exchange rate uncertainty and international portfolio flows: A multivariate GARCHin-mean approach," J. Int. Money Financ., vol. 54, no. November 2014, pp. 70-92, 2015, doi: 10.1016/j.jimonfin.2015.02.020.

[22] M. Fidora, M. Fratzscher, and C. Thimann, "Home bias in global bond and equity markets: The role of real exchange rate volatility," J. Int. Money Financ., vol. 26, no. 4, pp. 631-655, 2007, doi: 10.1016/j.jimonfin.2007.03.002.

[23] S. J. Peiris, "Foreign participation in emerging markets local currency bond markets," IMF Work. Pap., vol. WP/10/88, 2010.

[24] H. M. Lee, "Effects of foreign investor participation on emerging market sovereign bond yields and volatility," Northwest. Univ., 2014.

[25] N. Unal, "Impact of foreign investor participation on emerging market local currency government bond yields," Georg. Univ., 2018.

[26] C. Ebeke and A. Kyobe, "Global financial spillovers to emerging 
market sovereign bond markets," IMF Work. Pap., vol. WP/15/141, 2015 .

[27] J. R. Andritzky, "Government bonds and their investors: What are the facts and do they matter?," IMF Work. Pap., vol. WP/12/158, 2012.

[28] C. Ebeke and Y. Lu, "Emerging market local currency bond yields and foreign holdings in the post-Lehman period - a fortune or misfortune ?,"IMF Work. Pap., vol. WP/14/29, 2014.

[29] B. Gadanecz, K. Miyajima, and C. Shu, "Emerging market local currency sovereign bond yields: The role of exchange rate risk," Int. Rev. Econ. Financ., vol. 57, no. February 2016, pp. 371-401, 2018, doi: 10.1016/j.iref.2018.02.004.

[30] P. Turner, "The global long-term interest rate, financial risks and policy choices in EMEs," BIS Work. Pap., no. 441, 2014.

[31] B. Hofmann, I. Shim, and H. S. Shin, "Sovereign yields and the risktaking channel of currency appreciation," BIS Work. Pap., vol. No. 538, no. 538, 2017.

[32] W. Kang, R. A. Ratti, and K. H. Yoon, "The impact of oil price shocks on U.S. bond market returns," Energy Econ., vol. 44, pp. 248-258, 2014, doi: 10.1016/j.eneco.2014.04.009.

[33] M. K. Tule, U. B. Ndako, and S. F. Onipede, "Oil price shocks and volatility spillovers in the Nigerian sovereign bond market," Rev. Financ. Econ., vol. 35, pp. 57-65, 2017, doi: 10.1016/j.rfe.2017.03.003.

[34] N. Naifar and S. Hammoudeh, "Do global financial distress and uncertainties impact GCC and global sukuk return dynamics?," Pacific Basin Financ. J., vol. 39, pp. 57-69, 2016, doi: 10.1016/j.pacfin.2016.05.016.

[35] H. Nguyen, H. Nguyen, and A. Pham, "Impact of oil price fluctuations on financial markets since 2014," World Bank, Policy Res. Work. Pap., no. 7957, 2017, doi: 10.1111/opec.12046.

[36] J. Baek and J.-Y. Seo, "A study on unobserved structural innovations of oil price: evidence from global stock, bond, foreign exchange, and energy markets," Rev. Pacific Basin Financ. Mark. Policies, vol. 18, no. 01, p. 1550004, 2015, doi: 10.1142/s0219091515500046.

[37] S. Wanke, "Economics in brief oil prices and bond yields - hand-inhand again," KfW Res., no. 140, p. 2017, 2017. 
[38] B. Hayo and A. M. Kutan, "The impact of news, oil prices, and global market development on Russian financial markets," William Davidson Inst. Work. Pap., no. 656, 2004.

[39] T. Warwick-Ching, The International Gold Trade. Cambridge: Woodhead Publishing Limited, 1993.

[40] P. K. Narayan, K. S. Thuraisamy, and N. F. Wagner, "How do bond, equity and commodity cycles interact?," Financ. Res. Lett., vol. 21, pp. 151-156, 2017, doi: 10.1016/j.frl.2016.11.005.

[41] S. W. Sumner, R. Johnson, and L. Soenen, "Spillover effects among gold, stocks, and bonds," J. Cent. Cathedra Bus. Econ. Res. J., vol. 3, no. 2, pp. 106-120, 2012, doi: 10.7835/jcc-berj-2010-0041.

[42] Y. Seetharam, and L. Bodington, "Gold in the South African market: A safe haven or hedge?," Appl. Econ. Q., vol. 61, no. 4, pp. 331-352, 2016, doi: 10.3790/aeq.61.4.331.

[43] T. H. Van Hoang, H. H. Lean, and W. K. Wong, "Is gold good for portfolio diversification? A stochastic dominance analysis of the Paris stock exchange," Int. Rev. Financ. Anal., vol. 42, no. 1467200501, pp. 98-108, 2015, doi: 10.1016/j.irfa.2014.11.020.

[44] D. G. Baur and B. M. Lucey, "Is gold a hedge or a safe haven? An analysis of stocks, bonds and gold," Financ. Rev., vol. 45, no. 2, pp. 217-229, 2010, doi: 10.1111/j.1540-6288.2010.00244.x.

[45] R. Robiyanto, "Gold VS bonds: What is the safe haven for the indonesian and Malaysian capital market?," Gadjah Mada Int. J. Bus., vol. 20, no. 3, pp. 277-302, 2018, doi: 10.22146/gamaijb. 27775.

[46] B. D. Jordan, T. W. Miller Jr, and S. D. Dolvin, Fundamentals of investments valuation and management, Sixth. New York: McGrawHill Education, 2012.

[47] E. A. Purwanto and D. R. Sulistyastuti, Metode penelitian kuantitatif untuk administrasi publik dan masalah-masalah sosial, Edisi Kedu. Yogyakarta: Penerbit Gava Media, 2017.

[48] F. Williams and P. Monge, Reasoning with statistics How to read quantitative research, Fifth Edit. Boston: Wadsworth Cengage Learning, 2001.

[49] Sugiyono, Metode penelitian kuantitatif, kualitatif dan $R \& D$. Bandung: PT Alfabet, 2016. 
[50] N. D. Nachrowi and H. Usman, Pendekatan popoler dan praktis ekonometrika untuk analisis ekonomi dan keuangan. Jakarta: Lembaga Penerbit Fakultas Ekonomi Universitas Indonesia, 2006.

[51] M. Ekananda, Analisis ekonometrika time series, Edisi Kedu. Jakarta: Mitra Wahana Media, 2016.

[52] D. N. Gujarati, Basic econometrics, Fourth Ed. McGraw-Hill Companies, 2004.

[53] F. L. Alt, "Distributed Lags," Econometrica, vol. 10, 1942.

[54] J. Tinbergen, "Long-term foreign trade elasticities," Metroeconomica, vol. 10, 1949.

[55] Statistics Indonesia, "Neraca perdagangan beberapa negara juta US 2000-2014," 2019. .

[56] Statistics Indonesia, "Tabel dinamis subjek ekspor-impor," 2019. . 